\title{
Seasonal Variations in Serological Profiles and Growth Status of Farmed and Wild Clarias gariepinus (Burchell, 1822) Obtained from Asaba, Nigeria
}

Agatha Arimiche Nwabueze and Juliana Regha-John

Department of Fisheries, Delta State University, Asaba Campus, Asaba, P.M.B. 95074, Delta State, Nigeria

\begin{abstract}
Seasonal variations in serological profiles and growth status of farmed and wild Clarias gariepinus were investigated. Serological profiles of Clarias gariepinus can be an effective tool for proper monitoring of stress induced by management practices in intensive fish culture, which may elicit devastating effect on fish. Spectrophotometry procedures were used to analyze serum parameters of Clarias gariepinus. No different seasonal patterns were observed for mean values of albumin, total protein, urea, cholesterol, glucose and alanine amino-transferase. However, aspartate amino-transferase showed different seasonal pattern. Levels of cholesterol and alanine amino-transferase were highly significant in farmed and wild fish, separately. Juvenile fish had high level of urea irrespective of season. Seasonal variations in water quality parameters were observed except for $\mathrm{pH}$ which had no seasonal pattern. The growth exponential shows $b$-values between -0.048 and 7.434 for Clarias gariepinus. Adult female and juvenile fish from the wild had the highest $b$-value and the least $b$-value, separately. In this study, $b$-values were higher in the wild fish than the farmed fish. The condition factor for Clarias gariepinus ranged from 0.422 to 0.698 , and was observed to be high in juvenile fish. With a condition factor less than 1, fish may not be doing well, probably due to environmental stress. Some serological parameters varied according to season and environment of fish. Thus, serological profile of fish is an effective and sensitive tool to monitor fish response to stress factors in the environment.
\end{abstract}

Key words: Serology, Clarias gariepinus, farmed fish, wild fish, Asaba, Nigeria.

\section{Introduction}

Fish is one of the most valuable sources of cheap protein available to Nigerians. This has led to a high demand for fish, which has necessitated an increase in pisciculture with management practices that could cause a lot of stress to farmed fish [1]. Intensive fish culture has been associated with effects of chronic stress, such as reduction of growth rate, alteration in physical condition, health of fish and activation of stress responses [2]. Management procedures as crucial as they are, produce some level of disturbances, which can elicit a stress response leading to the decreased fish performance, alterations of the blood parameters [3, 4], the increased susceptibility to

Corresponding author: Agatha Arimiche Nwabueze, Ph.D., research fields: hydrobiology, fisheries and fish parasitology. E-mail: aanwabueze@gmail.com. diseases [5] and in extreme cases leading to mortality [6]. Environmental degradation resulting in aquatic pollution has also taken its toll on wild fish populations. Fish therefore is exposed to stress and frequent disease outbreaks [7]. Fish is disposed to a number of diseases, and unfortunately there are few diagnostic tools available to fish health professionals to evaluate these diseases. Haematological parameters are considered as patho-physiological indication of the whole body, and therefore are important in diagnosing the structural and functional diseases of fish and assessing the status of fish heath [8]. Haematological studies on most tropical fishes have focused on haematological parameters rather than on blood serum, thereby creating an imbalance between available research information in haematological and serum characteristics of fish. Serological parameters have been reported to be closely related to fish response to 
the environment in which it lives [9]. Serological values of fish are generally used as effective and sensitive tool to monitor physiological and pathological changes in fish with respect to different environmental conditions. Thus, serology is a valuable diagnostic tool in evaluating the health status of fish under different environmental conditions, as the normal composition of serum and other tissues of the fish may be changed by the various conditions prevailing in the environment including diseases [10,11]. Management procedures with and without apparent warning may elicit very distressing effect on fish. Thus, baseline information on the serum profile of Clarias gariepinus is necessary for proper monitoring of stress in fish in order to reduce to the negative effect of management procedures. This study examined the serum characteristics of farmed and wild Clarias gariepinus - a common catfish, which has been widely adopted as a choice culture species in Nigeria.

\section{Materials and Methods}

\subsection{Collection of Fish Samples}

One hundred and eighty Clarias gariepinus samples were collected in six months between November, 2012 and January, 2013, representing the dry season, and between May and July, 2013, representing the rainy season.

Ninety Farmed fish samples were collected from Obiora farms in Asaba and 90 wild fish samples were collected from local fisher folks who caught the fish with traps at Ona Lake in Delta state (Fig. 1). Thirty Clarias gariepinus fish-15 from farm and 15 from wild, with each 15 made up of five male, five female and five juvenile fish, were bought once every month. Fish samples were obtained on the same day and were separately transported live in $30 \mathrm{~L}$ open plastic bucket, containing little amount of water from the different sources of procurement to the laboratory.

\subsection{Biometric Measurements}

Fish samples were measured for weight (g), standard length $(\mathrm{cm})$ and total length $(\mathrm{cm})$ using the lark model (LP 302A) electric weighing balance and measuring board, respectively. Adult and juvenile fish were used approximately of the same size ranges. Fish weight ranged from $480.2 \mathrm{~g}$ to $501.5 \mathrm{~g}$ and fish standard length ranged from $41 \mathrm{~cm}$ to $55 \mathrm{~cm}$ for adult fish; while fish weight ranged from $65.14 \mathrm{~g}$ to 211.91 $\mathrm{g}$ and total length ranged from $21 \mathrm{~cm}$ to $31 \mathrm{~cm}$ for juvenile fish for both farmed and wild fish samples.

\subsection{Collection of Fish Blood Serum Samples}

To avoid mixing the farmed and wild fish samples together, fish samples were maintained in separate glass tanks $(45 \times 45 \times 90 \mathrm{~cm})$ and handled separately. Physical stress on fish was avoided by handling each fish gently as the blood samples were drawn from the pectoral caudal vein with the aid of a sterile disposable clinical $5 \mathrm{~mL}$ syringe and needle. The needles were inserted at right angle of the vertebral column of each fish and were gently aspirated during penetration. The needles were pushed down until blood started entering the syringe. The needle was withdrawn after $3.0 \mathrm{~mL}$ of blood was drawn and immediately transferred into a microcentrifuge test tube.

\subsection{Experimental Procedure}

The blood collected from each fish sample was transferred into separate sterile tubes and allowed to clot for a few minutes (approximately 3-5 min) before centrifugation at $4,000 \mathrm{rpm}$ for $5 \mathrm{~min}$ at $4{ }^{\circ} \mathrm{C}$ to isolate the serum using a table centrifuge model 800 . Serum samples were transferred to another labelled sterile tube. The labelled sterile tubes were placed in ice and stored at $70{ }^{\circ} \mathrm{C}$ prior to analyses.

\subsection{Serological Analyses}

The frozen serum samples were left at room temperature to thaw. Serum sample for each individual fish from both farmed and wild sources was analyzed for the following parameters: albumin (ALB, 
$\mathrm{g} / \mathrm{L}$ ), total protein $(\mathrm{TP}, \mathrm{g} / \mathrm{L}$ ), urea $(\mathrm{UR}, \mathrm{mmol} / \mathrm{L})$, cholesterol (TC, mmol/L), glucose (GLU, mmol/L) alanine amino-transferases (ALT, U/L) and aspertate amino-transferases (AST, U/L), which were determined by spectophotometry using serological kit (biosystem, Barceiona, Spain), 2ID PEC (medical USA) according to Fatih et al. [12] and Gul et al. [13].

\subsection{Water Quality Parameters}

Water quality parameters, such as temperature $\left({ }^{\circ} \mathrm{C}\right)$, $\mathrm{pH}$, dissolved oxygen $(\mathrm{mg} / \mathrm{L})$, transparency $(\mathrm{cm})$ and suspended matter $(\mathrm{g} / 100 \mathrm{~mL})$, were determined according to American Public Health Association (APHA) [14].

\subsection{Length Weight Relationship (LWR) of Fish}

The LWR was determined from Eq. (1):

$$
W=a L^{b}
$$

The parameters $a$ and $b$ in the formula were estimated through logarithmic transformation in Eq. (2):

$$
\log W=\log a+b \log L
$$

where,

$W=$ body weight of fish (g);

$L=$ total length of fish $(\mathrm{cm})$;

$b=$ growth exponent or regression coefficient;

$\log a=$ intercept on the $Y$-axis.

\subsection{Condition Factor (K) of Fish}

The condition factor $(K)$ was estimated from the relationship in Eq. (3):

$$
K=\frac{100 W}{L^{3}}
$$

where, $K$ is condition factor, $L$ is standard length of fish $(\mathrm{cm})$ and $W$ is weight of fish $(\mathrm{g})$.

\subsection{Statistical Analysis}

A one-way analysis of variance was used to determine variability in serological parameters. Paired $t$-test was used to compare serological values between the farmed and wild C. gariepinus and for seasonal variation in serological values.

\section{Results}

\subsection{Seasonal Variations in Serological Profiles of Farmed and Wild Fish}

Seasonal variations in mean values of serological profiles of farmed and wild adult and juvenile Clarias gariepinus are presented in Tables 1 and 2. Mean values of albumin obtained for adult male, adult female and juvenile $C$. gariepinus did not show any seasonal pattern. Wild juvenile fish had high mean values of albumin irrespective of season (Fig. 2). Fig. 3 shows that juvenile fish had high mean values of total protein in both dry and rainy seasons.

These values were, however, not significantly $(P>$ 0.05 ) higher than values obtained for adult female and adult male fish. The level of urea was higher in

\begin{tabular}{|c|c|c|c|c|c|c|}
\hline \multirow{2}{*}{ Serological parameters } & \multicolumn{3}{|c|}{ Farmed fish } & \multicolumn{3}{|c|}{ Wild fish } \\
\hline & Adult male & Adult female & Juvenile & Adult male & Adult female & Juvenile \\
\hline Albumin (g/dL) & $3.46 \pm 0.68$ & $2.51 \pm 0.45$ & $2.32 \pm 0.76$ & $3.03 \pm 0.30$ & $3.40 \pm 0.34$ & $2.87 \pm 0.34$ \\
\hline Total protein $(\mathrm{g} / \mathrm{dL})$ & $3.50 \pm 0.37$ & $4.35 \pm 0.53$ & $3.40 \pm 0.35$ & $4.59 \pm 0.60$ & $3.71 \pm 0.44$ & $6.08 \pm 0.58$ \\
\hline Urea $(\mathrm{mmol} / \mathrm{L})$ & $2.04 \pm 0.15$ & $2.56 \pm 0.13$ & $4.11 \pm 0.54^{*}$ & $1.30 \pm 0.06$ & $1.27 \pm 0.03$ & $1.65 \pm 0.19$ \\
\hline Cholesterol (mmol/L) & $27.70 \pm 0.29 *$ & $25.48 \pm 0.38^{*}$ & $30.13 \pm 1.7^{*}$ & $9.33 \pm 1.94$ & $18.32 \pm 4.83$ & $13.53 \pm 0.99$ \\
\hline Glucose (mmol/L) & $4.17 \pm 0.61$ & $5.20 \pm 0.49$ & $5.13 \pm 0.51$ & $3.00 \pm 0.31$ & $3.37 \pm 0.32$ & $6.88 \pm 0.78$ \\
\hline Alanine amino-transferase (U/L) & $1.88 \pm 0.28$ & $1.92 \pm 0.35$ & $1.40 \pm 0.04$ & $3.03 \pm 0.49$ & $3.01 \pm 0.24$ & $2.31 \pm 0.45$ \\
\hline Aspertate amino-transferase (U/L) & $1.28 \pm 0.12$ & $2.01 \pm 0.55$ & $1.61 \pm 0.12$ & $1.88 \pm 0.12$ & $1.49 \pm 0.10$ & $1.41 \pm 0.23$ \\
\hline Weight $(\mathrm{g})$ & $494.16 \pm 3.73$ & $494.22 \pm 3.97$ & $143.03 \pm 29.3$ & $494.18 \pm 3.84$ & $494.36 \pm 3.79$ & $114.30 \pm 25.52$ \\
\hline Total length $(\mathrm{cm})$ & $47.20 \pm 1.65$ & $48.40 \pm 2.56$ & $27.00 \pm 1.58$ & $47.40 \pm 1.69$ & $47.40 \pm 1.93$ & $25.00 \pm 1.78$ \\
\hline
\end{tabular}
farmed fish than wild fish, and higher in juvenile fish

Table 1 Seasonal variation (dry season) in mean values of serological parameters of farmed and wild Clarias gariepinus.

*Means significant values at $95 \%$ confidence level. 
Table 2 Seasonal variation (rainy season) in mean values of serological parameters of farmed and wild Clarias gariepinus.

\begin{tabular}{|c|c|c|c|c|c|c|}
\hline \multirow{2}{*}{ Serological parameters } & \multicolumn{3}{|c|}{ Farmed fish } & \multicolumn{3}{|c|}{ Wild fish } \\
\hline & Adult male & Adult female & Juvenile & Adult male & Adult female & Juvenile \\
\hline Albumin (g/dL) & $3.61 \pm 0.23$ & $3.68 \pm 0.11$ & $2.26 \pm 0.14$ & $3.01 \pm 0.09$ & $3.54 \pm 0.17$ & $2.96 \pm 0.19$ \\
\hline Total protein $(\mathrm{g} / \mathrm{dL})$ & $3.68 \pm 0.14$ & $4.70 \pm 0.21$ & $3.56 \pm 0.38$ & $3.35 \pm 0.14$ & $4.57 \pm 0.21$ & $4.69 \pm 0.38$ \\
\hline Urea $(\mathrm{mmol} / \mathrm{L})$ & $2.21 \pm 0.08$ & $2.26 \pm 0.10$ & $3.73 \pm 0.13$ & $2.12 \pm 0.09$ & $2.10 \pm 0.11$ & $3.57 \pm 0.13$ \\
\hline Cholesterol (mmol/L) & $28.07 \pm 1.39^{*}$ & $31.65 \pm 3.39 *$ & $32.30 \pm 2.47^{*}$ & $14.47 \pm 1.86$ & $20.29 \pm 1.25$ & $15.8 \pm 1.19$ \\
\hline Glucose (mmol/L) & $4.81 \pm 0.37$ & $6.39 \pm 0.47$ & $6.26 \pm 0.39$ & $4.96 \pm 0.24$ & $5.94 \pm 0.32$ & $5.68 \pm 0.31$ \\
\hline Alanine amino-transferase (U/L) & $1.98 \pm 0.30$ & $2.23 \pm 0.12$ & $2.60 \pm 0.32$ & $3.66 \pm 0.30$ & $3.53 \pm 0.12$ & $2.60 \pm 0.32$ \\
\hline Aspertate amino-transferase (U/L) & $5.50 \pm 0.91$ & $5.23 \pm 0.75$ & $1.62 \pm 0.17$ & $4.28 \pm 0.68$ & $4.12 \pm 0.59$ & $1.74 \pm 0.11$ \\
\hline Weight $(g)$ & $487.05 \pm 3.33$ & $466.44 \pm 10.61$ & $115.35 \pm 7.84$ & $492.13 \pm 3.27$ & $493.03 \pm 6.09$ & $122.08 \pm 13.62$ \\
\hline Total length $(\mathrm{cm})$ & $44.79 \pm 0.62$ & $46.17 \pm 0.66$ & $25.35 \pm 0.79$ & $48.45 \pm 0.57$ & $69.69 \pm 12.67$ & $26.91 \pm 0.93$ \\
\hline
\end{tabular}

*Means significant values at $95 \%$ confidence level.

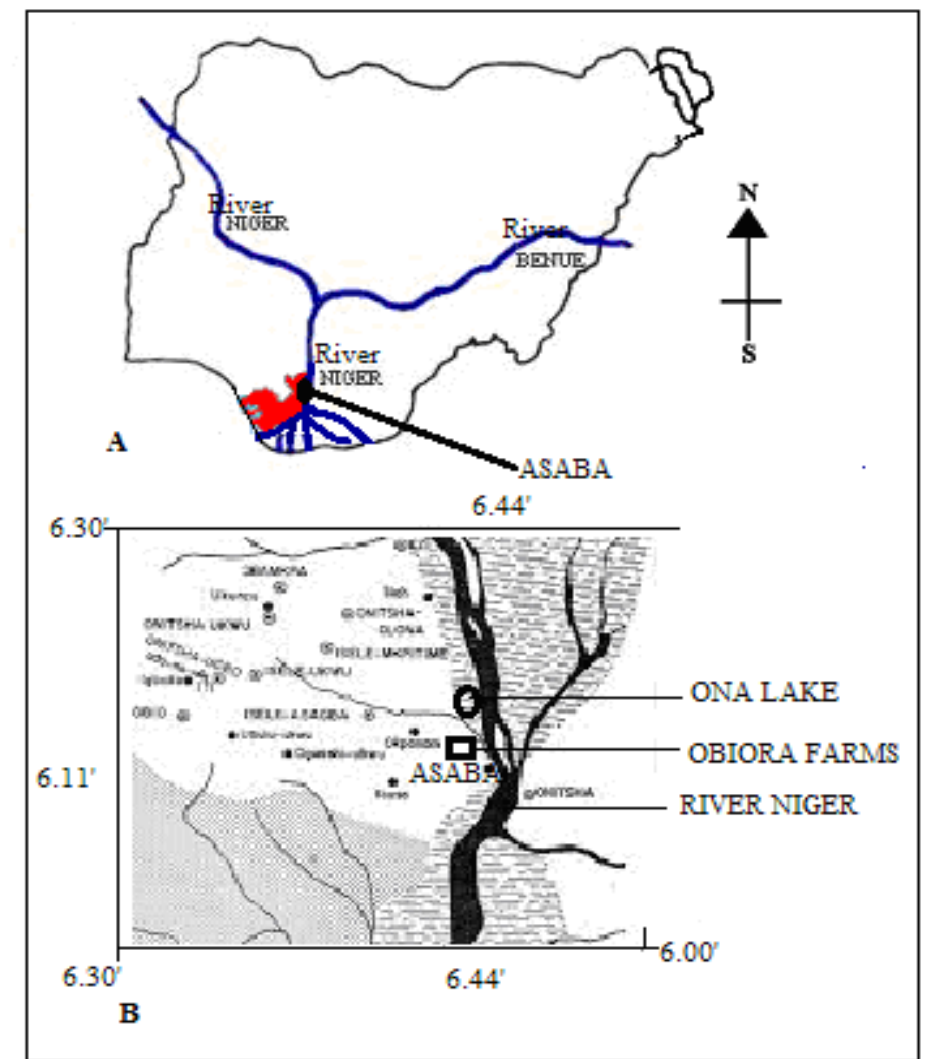

Fig. 1 Map of Nigeria showing Delta State at Asaba (A) and map of Asaba and environs showing sampling locations, Ona Lake and Obiora Farms (B).

Adapted from www.Nigeria.com/map.

than in the adult farmed and wild male and female fish (Fig. 4). Urea was highly significant $(P<0.05)$ in juvenile fish sourced from the farm in the dry season. Mean values of cholesterol showed a seasonal pattern of variation. Cholesterol levels were significantly $(P<$ $0.05)$ higher in fish sourced from the farm than fish from the wild irrespective of season, size and sex of fish (Fig. 5). The level of glucose was high in adult female and juvenile fish in farm and wild in both the rainy and dry seasons (Fig. 6). Mean values of alanine amino-transferase were generally higher in the wild fish than farmed fish irrespective of season (Fig. 7). Mean values of aspartate amino-transferase were higher $(P<$ $0.05)$ in rainy season than dry season (Fig. 8). Adult 


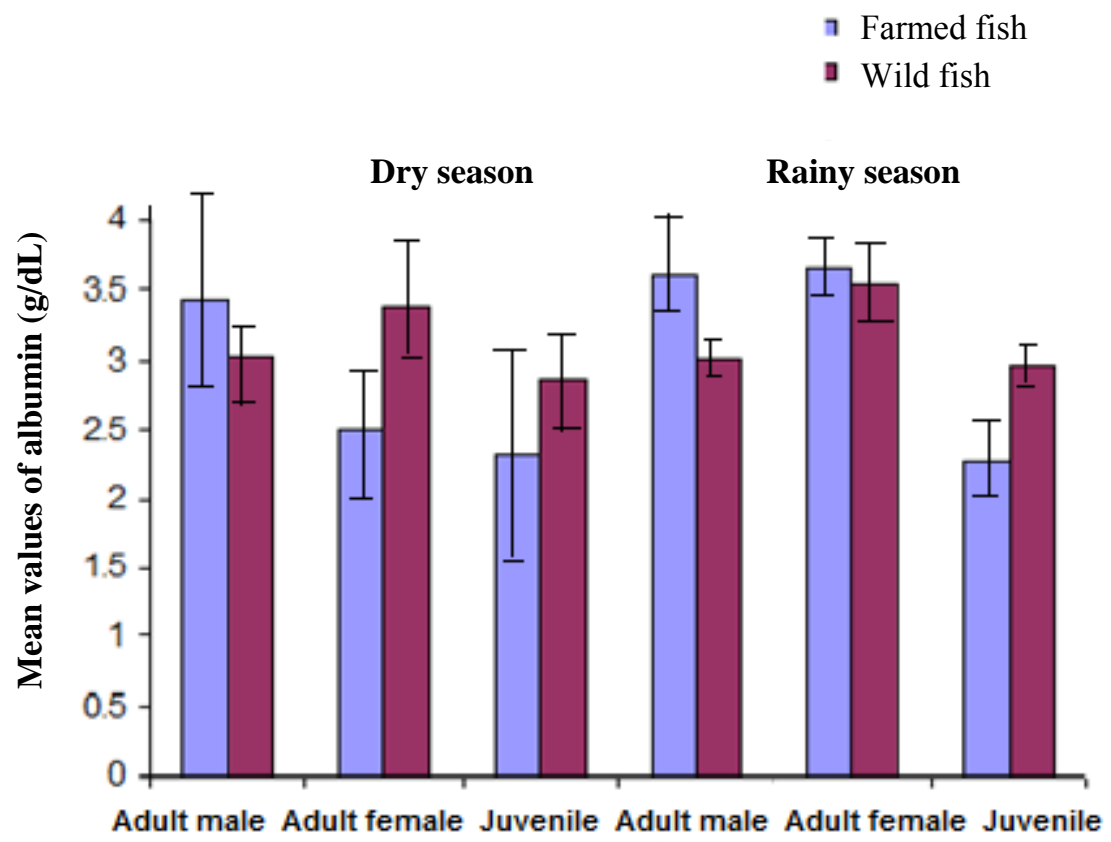

Fig. 2 Mean values of albumin in farmed and wild Clarias gariepinu (with standard error as vertical bars).

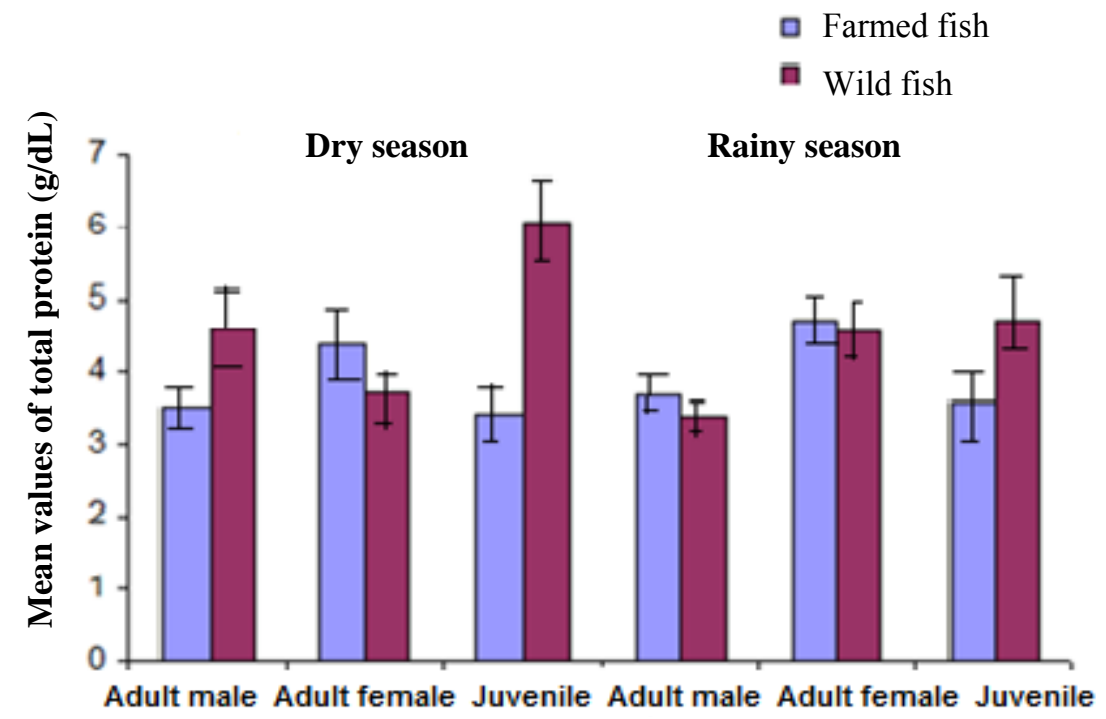

Fig. 3 Mean values of total protein in farmed and wild Clarias gariepinus (with standard error as vertical bars).

male and female had higher $(P>0.05)$ mean values of aspartate amino-transferase than juvenile fish.

\subsection{Seasonal Variation in Water Quality Parameters}

Seasonal variation in water quality parameters is presented in Table 3. Temperature was highest in the culture pond during the dry season and lowest in the culture pond in the rainy season. Dissolved oxygen was highest in the wild and least in the culture pond during the rainy season. $\mathrm{pH}$ values were high in the wild during the rainy season. Secchi disc transparency was observed to have high values in the rainy season. This shows that the water was more transparent in the dry season than in the rainy season. The water was also clearer in the wild than in the culture water. Suspended matter was higher in the rainy season than 


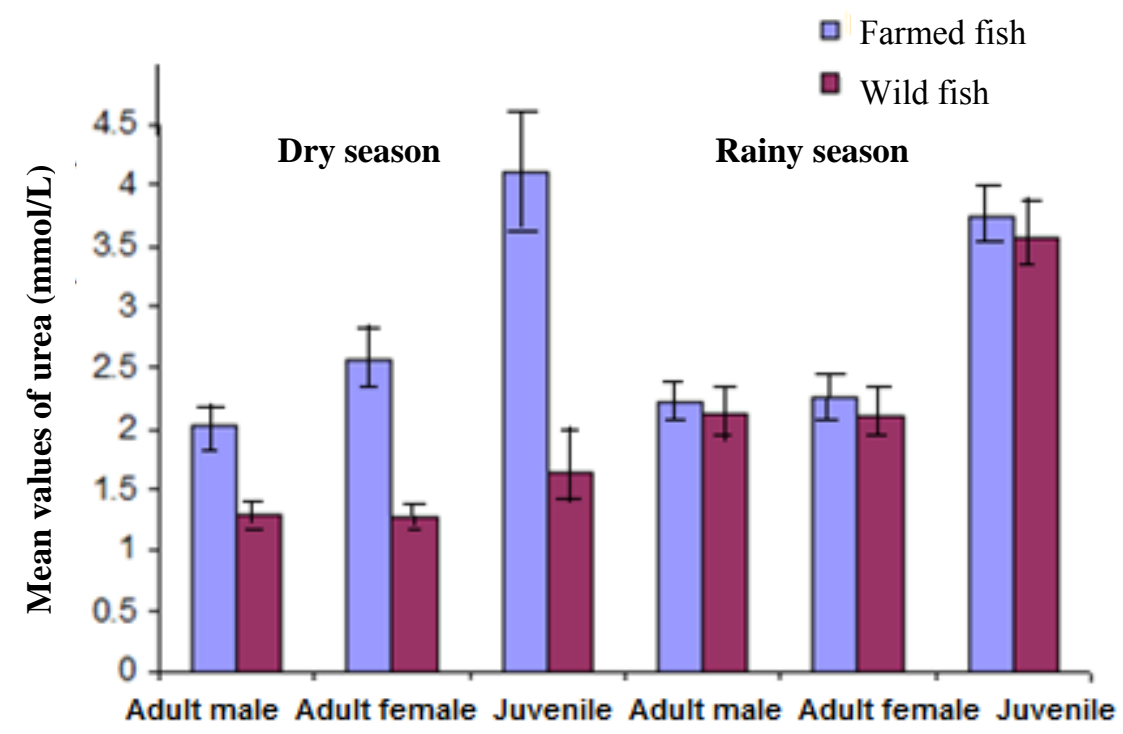

Fig. 4 Mean values of urea in farmed and wild Clarias gariepinus (with standard error as vertical bars).

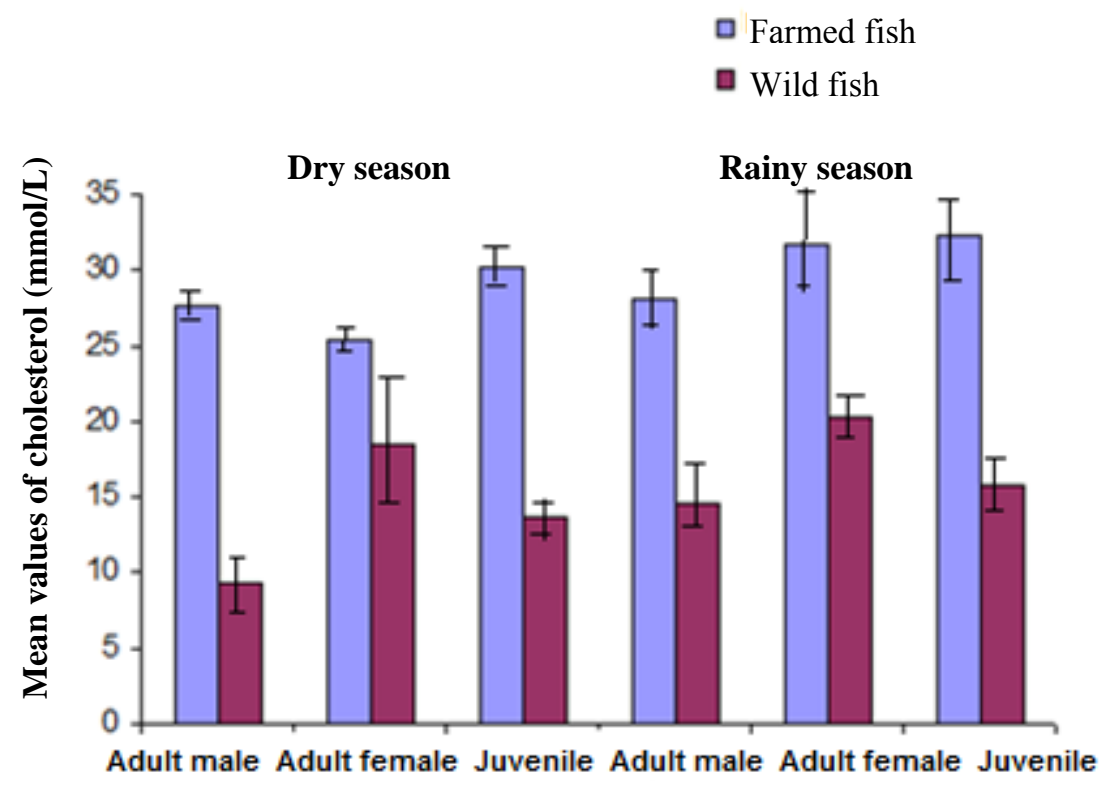

Fig. 5 Mean values of cholesterol in farmed and wild Clarias gariepinu (with standard error as vertical bars).

in the dry season. The water from the wild was generally lower in suspended matter than the water sourced from farmed source.

\subsection{LWR}

Parameters of LWR obtained in this study were presented in Table 4. The $b$-values for this species for adult male, adult female and juvenile C. gariepinus ranged from -0.048 to 7.434 . Adult female fish sourced from the wild during the dry season had the highest $b$-value, while juvenile fish also sourced from the wild during the dry season had the least $b$-value. The $b$-values obtained in this study were observed to be generally higher in fish sourced from the wild than in fish sourced from the farm.

\subsection{Condition Factor (K)}

Results of analysis for condition factors $(K)$ of fish 
๑ Farmed fish

a Wild fish

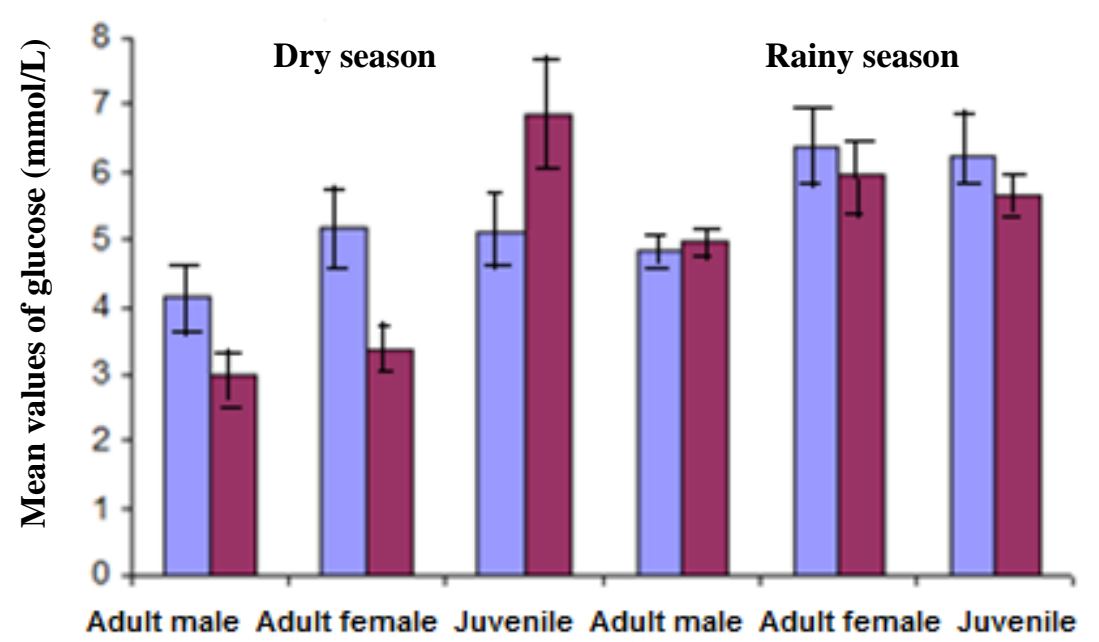

Fig. 6 Mean values of glucose in farmed and wild Clarias gariepinus (with standard error as vertical bars).

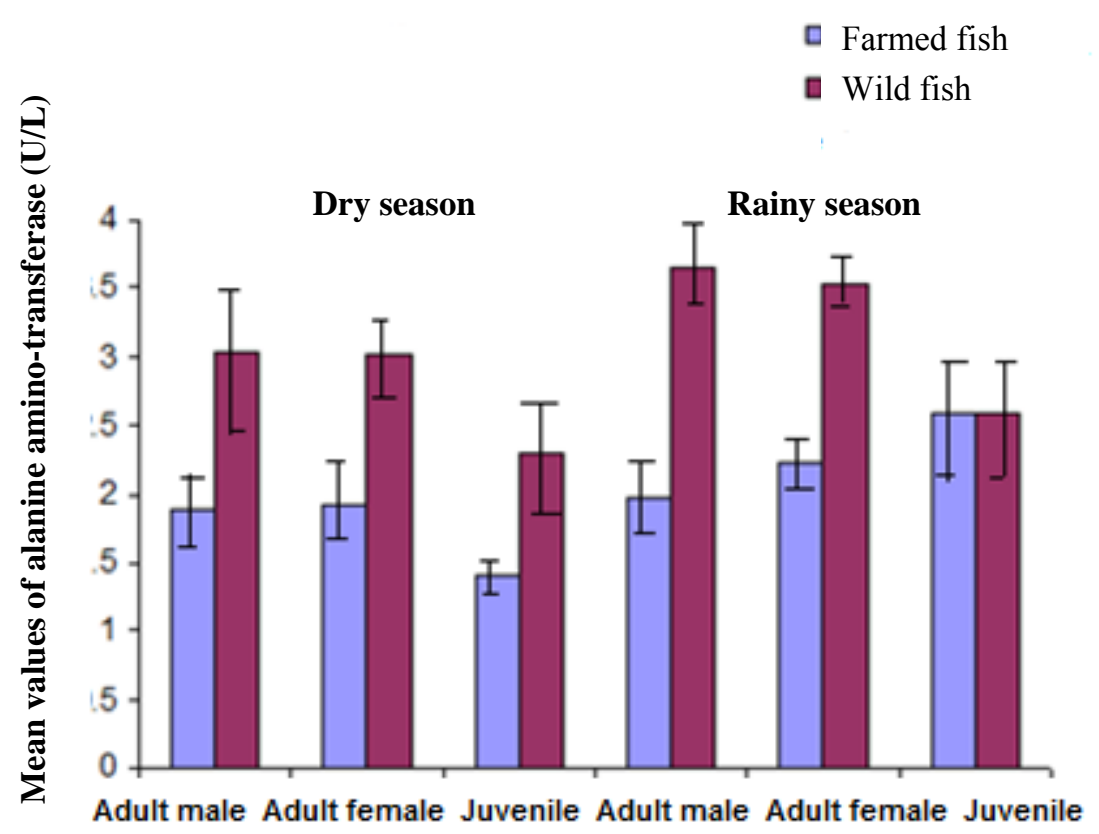

Fig. 7 Mean values of alanine amino-transferase in farmed and wild Clarias gariepinus (with standard error as vertical bars).

are presented in Table 5. The condition factor for $C$. gariepinus in farmed and wild female fish ranged from 0.422 to 0.4640 , and ranged from 0.6673 to 0.698 in wild juvenile fish. Seasonal variation in mean condition factor $(K)$ shows that the condition factor of C. gariepinus was slightly but not significantly $(P>$
0.05 ) higher during the dry season than in the rainy season. Juvenile $C$. gariepinus generally had higher $K$ than the male and female C. gariepinus. The female fish had the least $K$. Farmed fish had slightly higher $K$ than the wild fish. The maximum value of $K$ was obtained in adult female in the dry season. 


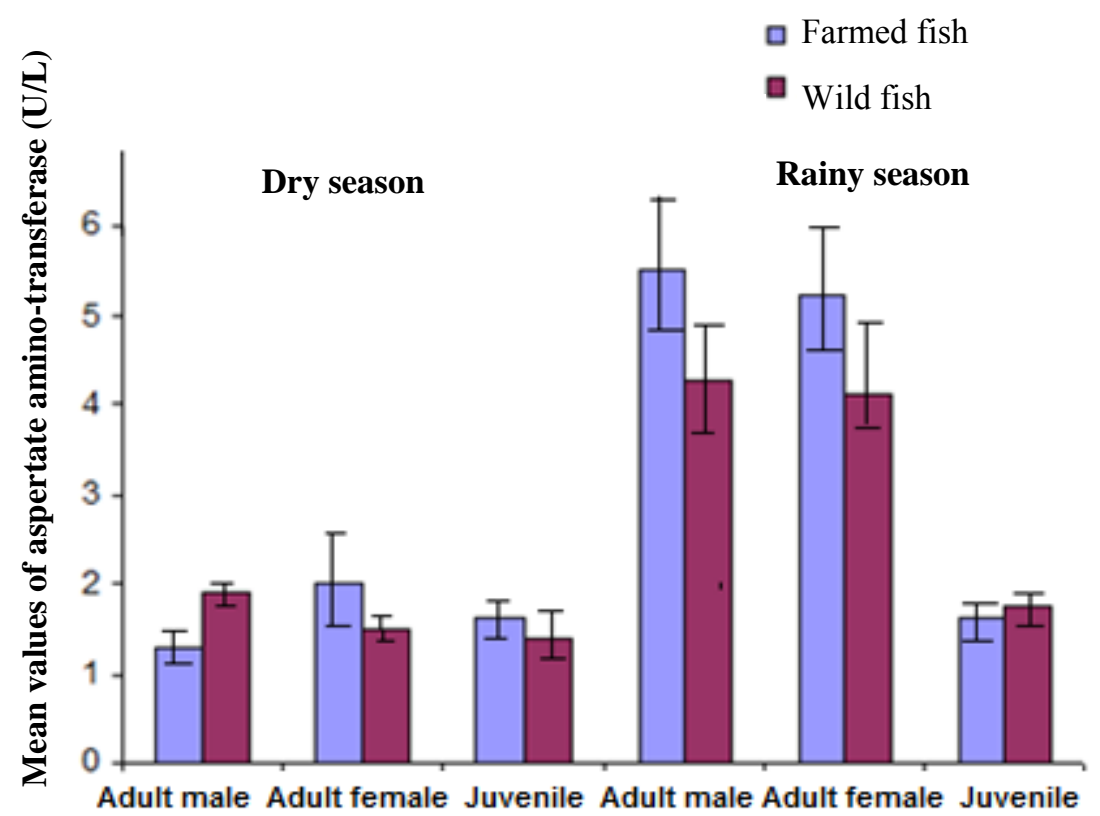

Fig. 8 Mean values of aspertate amino-transferase in farmed and wild Clarias gariepinus (with standard error as vertical bars).

Table 3 Seasonal variation in mean water quality parameter of farm and wild.

\begin{tabular}{llllll}
\hline Parameter & \multicolumn{2}{c}{ Dry season } & & \multicolumn{2}{c}{ Rainy season } \\
\cline { 2 - 3 } \cline { 5 - 6 } & Farmed & Wild & & Farmed & Wild \\
\hline Temperature $\left({ }^{\circ} \mathrm{C}\right)$ & $30.10 \pm 0.30$ & $29.70 \pm 0.10$ & & $26.40 \pm 0.60$ & $26.60 \pm 0.30$ \\
Dissolved oxygen $(\mathrm{mg} / \mathrm{L})$ & $4.20 \pm 0.1$ & $4.50 \pm 0.20$ & & $3.80 \pm 0.20$ & $4.9 \pm 0.50$ \\
$\mathrm{pH}$ & $6.40 \pm 1.0$ & $6.10 \pm 0.40$ & & $6.90 \pm 0.10$ & $7.1 \pm 0.60$ \\
Transparency $(\mathrm{cm})$ & $21.00 \pm 0.5$ & $19.00 \pm 0.20$ & & $26.50 \pm 0.40$ & $24.13 \pm 0.50$ \\
Suspended matter $(\mathrm{g} / 100 \mathrm{~mL})$ & $1.32 \pm 0.2$ & $0.99 \pm 0.70$ & & $1.10 \pm 0.00$ & $1.73 \pm 0.10$ \\
\hline
\end{tabular}

Table 4 Length-weight relationships and related statistics of farmed and wild Clarias gariepinus.

\begin{tabular}{llllllll}
\hline Fish samples & BWT $(\mathrm{g})$ & $\mathrm{TL}(\mathrm{cm})$ & $\mathrm{R}$ & $\mathrm{A}$ & $\mathrm{B}$ & $\mathrm{F}$ & $P$ value \\
\hline DAFM & $500.15 \pm 2.83$ & $49.25 \pm 0.76$ & 0.000 & 1.390 & 0.356 & 0.000 & 1.000 \\
DAFF & $497.86 \pm 1.93$ & $50.29 \pm 0.92$ & 0.125 & -0.763 & 1.156 & 0.096 & 0.909 \\
DFJ & $143.18 \pm 14.81$ & $27.45 \pm 0.78$ & 0.563 & 1.159 & 0.196 & 1.703 & 0.224 \\
DAWM & $497.19 \pm 2.02$ & $49.46 \pm 0.85$ & 0.678 & -11.630 & 3.209 & 2.122 & 0.153 \\
DAWF & $496.03 \pm 1.54$ & $49.32 \pm 0.71$ & 0.737 & -29.738 & 7.434 & 2.145 & 0.151 \\
DWJ & $110.76 \pm 13.20$ & $24.69 \pm 0.91$ & 0.743 & -30.766 & -0.048 & 1.644 & 0.252 \\
RAFM & $487.05 \pm 3.33$ & $44.79 \pm 0.62$ & 0.765 & -19.694 & -1.853 & 1.412 & 0.330 \\
RAFF & $466.44 \pm 10.62$ & $46.13 \pm 0.66$ & 0.776 & -22.298 & -0.259 & 1.136 & 0.451 \\
RFJ & $115.35 \pm 7.85$ & $25.35 \pm 0.79$ & 0.840 & -53.001 & 0.911 & 1.331 & 0.395 \\
RAWM & $492.13 \pm 3.27$ & $48.45 \pm 0.57$ & 0.144 & -0.443 & 0.694 & 0.277 & 0.608 \\
RAWF & $491.03 \pm 6.53$ & $48.37 \pm 1.09$ & 0.206 & 0.724 & -0.410 & 0.267 & 0.770 \\
RWJ & $122.09 \pm 13.62$ & $26.91 \pm 0.93$ & 0.891 & 0.556 & 0.287 & 14.064 & 0.000 \\
\hline R:COTr & & &
\end{tabular}

R: correlation coefficient, A: intercept, B: regression coefficient (slope), F: covariance.

DAFM: dry season adult farmed male; DAFF: dry season adult farmed female; DFJ: dry season juvenile; DAWM: dry season adult wild male; DAWF: dry season adult wild female; DWJ: dry season wild juvenile; RAFM: rainy season adult farmed male; RAFF: rainy season adult farmed female; RFJ: rainy season juvenile; RAWM: rainy season adult wild male; RAWF: rainy season adult wild female; RWJ: rainy season wild juvenile; BWT: body weight; TL: total length. 
Table 5 Seasonal variation in mean $( \pm S E)$ condition factor $(K)$ of farmed and wild Clarias gariepinus.

\begin{tabular}{|c|c|c|c|c|}
\hline \multirow{2}{*}{ Fish } & \multicolumn{2}{|c|}{ Dry season } & \multicolumn{2}{|c|}{ Rainy season } \\
\hline & Farmed & Wild & Farmed & Wild \\
\hline Male & $0.4820 \pm 0.02$ & $0.4780 \pm 0.02$ & $0.4450 \pm 0.02$ & $0.4427 \pm 0.17$ \\
\hline Female & $0.4640 \pm 0.03$ & $0.4480 \pm 0.03$ & $0.4227 \pm 0.03$ & $0.4227 \pm 0.03$ \\
\hline Juvenile & $0.6920 \pm 0.02$ & $0.6980 \pm 0.01$ & $0.6790 \pm 0.02$ & $0.6673 \pm 0.02$ \\
\hline
\end{tabular}

\section{Discussion}

Although no seasonal variations in mean values of albumin, total protein, urea and cholesterol were observed, farmed fish had higher mean values of albumin, total protein and cholesterol than wild fish. High levels of albumin have been attributed to environmental stress. Gras [15] observed relatively high albumin level in cultured Northern snakehead, which indicated that its concentration in serum is significantly influenced by environmental stress. Gabriel and Akinrotimi [1] noted that as aquaculture world over is becoming more and more intensive, manipulation of fish and other farm management procedures could produce some level of disturbances, which can elicit a stress response leading to decreased fish performance. Juvenile fish had high mean values of total protein and urea irrespective of seasons, which shows high protein in diet or increased protein catabolism. The elevation of serum urea may be due to the correlation between urea and increased protein catabolism or from more efficient conversion of ammonia to urea as a result of increased synthesis of enzyme involved in urea production [16]. Significantly higher values of cholesterol were observed in adult male, adult female and juvenile fish sourced from the farm than fish from the wild irrespective of season, size and sex of fish. Bender et al. [17] reported that small differences in body size do not result in significant changes in cortisol production and metabolism, which are related to elevated levels of cholesterol. Xu and Cao [18] and Coz-Rakovae et al. [19] also reported the elevated levels of cholesterol in farmed fishes. Furthermore, Yousafzai and Shakoori [20] reported that aquatic pollution leads to the elevated tissue cholesterol in fish. The high values in glucose observed in farmed fish are in line with the findings of Barton and Iwama [21] and Coz-Rakovae et al. [19], who reported the differences in glucose concentration as a secondary response to stress. Adeyemo et al. [22] noted that fishes are very susceptible to physical and chemical changes in the environment, which may be reflected in their blood components. Alanine amino-transferases and aspartate amino-transferases are among the most important indicators of innate immune response to stress [23]. Mean values of aspertate amino-transferase were generally higher in adult farmed fish than in the wild fish. Svoboda et al. [23] reported the elevated levels in farmed fish, which is indicative of impairment of liver function.

Seasonal pattern was observed in water temperature. Temperature has been reported to have effects on blood sugar, urea, uric acid and protein levels [24]. Like the observations of Egborge et al. [25] and Odum [26], there was no discernible seasonal pattern in the $\mathrm{pH}$. The water was more transparent in the dry season than rainy season. The dissolved oxygen in the wild water environment was better aerated than the culture medium.

Wild adult male and female studied exhibited positive allometric growth pattern with $b$-values $>3$. All other fish samples had negative allometric growth pattern. According to Sangun et al. [27], values of the exponent " $b$ " provide the information on fish growth, fish growth being isometric when " $b "=3$ and allometric when " $b$ " $\neq 3$, which could be negative (when " $b$ " $<3$ ) or positive (when " $b$ " $>3$ ). In the present study, the condition factor for $C$. gariepinus ranged from 0.422 to 0.4640 in farmed and wild female fish, and ranged from 0.6673 to 0.698 in 
farmed and wild juvenile fish, respectively. Condition factor less than 1 , could indicate that the fish is not doing well. Bagenal [28] documented that the condition factor of mature freshwater fish must to be in the range of 2.9-4.8. The mean " $K$ " obtained in this study disagrees with that in Ref. [29], which reported positive allometric growth but with high " $K$ " range of 0.91-8.66 and " $K$ " could be influenced by factors including prevailing environmental condition, availability of food, feeding intensity, density or population changes, the period and duration of gonadal maturation among others.

\section{Conclusions}

Albumin, total protein and alanine amino-transferase values were higher in wild fish than farmed fish, while urea, cholesterol, glucose and aspartate amino-transferase values were lower in wild fish compared to farmed fish. Stressors, including water quality parameters and seasons of the year, may have affected the serum biochemical parameters of Clarias gariepinus. The significant differences in some serological parameters in farmed and wild Clarias gariepinus could thereforebe attributed to different habitat conditions and the type of management practices.

\section{References}

[1] Gabriel, U. U., and Akinrotimi, O. A. 2011. "Management of Stress in Fish for Sustainable Aquaculture Development." Researcher 3 (4): 28-38.

[2] Baldwin, L. 2010. "The Effects of Stocking Density on Fish Welfare." The Plymouth Student Scientist 4 (1): 372-83.

[3] Maule, A. G., and Shreck, C. B. 1990. "Changes in Number of Leucocytes in Immune Organs of Juvenile Coho Salmon after Acute Stress of Contisol Treatment." J. Aqua. Ani. Health 2 (4): 298-304.

[4] Gabriel, U. U., Anyanwu, P. E., and Akinrotimi, O. A. 2007. "Blood Characteristics Associated with Confinement Stress in Black Chin Tilapia Sarotherodon melanotheron." J. Fish. Int. 2 (2): 186-9.

[5] Maule, A. G., Tripp, R. A., Kaatarist, A. Y., and Shreck, C. B. 1989. "Stress Alters Immune Functions and Disease Resistance in Chinook Salma (Oncorhynchus tshawytscha)." J. Endocrinol 120 (1): 135-42.

[6] Akinrotimi, O. A., Gabriel, U. U., Owhonda, N. K, Onunkwo, D. N., Opara, J. Y., Anyanwu, P., and Cliffe, P. T. 2007. "Formulating an Environmentally Friendly Fish Feed for Sustainable Aquaculture Development in Nigeria." Agric. J. 2 (5): 606-12.

[7] Francis-Floyd, R. 2009. "Stress-Its Role in Fish Diseases." IFAS Circular 919, Florida Cooperative Extension Service, University of Florida, Gainesville. Accessed August 11, 2015. http://edis.ifas.ufl.edu.

[8] Shah, S. L., and Altindag, A. 2004. "Hematological Parameters of Tench (Tinea tinca L., 1758) after Acute and Chronic Exposure to Lethal and Sublethal Mercuty Treatment." Bulletin of Environmental Contamination and Toxicology 73 (5): 911-8.

[9] Kori-Siakpere, O., Ake, J. E. G., and Idoge, E. 2005. "Haematological Characteristic of the African Snakehead, Parachanna obscura." African Journal of Biotechnology 4 (6): 527-30.

[10] Ahmad, A. F., Hadip, F., Ngui, R., Lim, Y. A., and Mahmud, R. 2013. "Serological and Molecular Detection of Strongyloides stercoralis Infection among an Orang Asli Community in Malaysia." Parasitol Res. 112 (8): 2811-6.

[11] Oluah, N. S., and Chineke, A. C. 2014. "Alterations in the Biochemical Parameters of the African Catfish, Clarias gariepinus (Burchell) Exposed to Sublethal Concentrations of Lambda-Cyhalothrin." Annals of Environmental Science 8: 1-7.

[12] Fatih, P., Sibel, K., Kursal, F., and Sahin, S. 2010. "Serum Electrolytes of Wild and Cultured Bluefin Tuna (Thunnus thynnus L.) on Turkish Sea." Journal of Animal and Advanced Veterinary 9 (16): 2207-13.

[13] Gul, Y., Gao, Z. X., Qian, X. Q., and Wangi, W. M. 2011. "Haematological and Serum Biochemical Characterization and Comparison of Wild and Cultured Northern Snake Head (Channa argus Cantor, 1842)." Journals of Applied Ichthyology 27 (1): 122-8.

[14] American Public Health Association (APHA). 1985. Standard Methods for the Examination of Water and Waste Water. Washington, DC: APHA.

[15] Gras, J. 1983. Protein as Plasma: Physicochemical Metabolism, Pathophysiological and Clinical Extracellular Proteins, 4th ed.. Barcelona: Jims Publishers.

[16] Sifa, L., Hong, S., and Zhijin, Z. 2000. "Strain-Specific and Sex Specific Variation of Serum Biochemical Components of Oreochromis niloticus." Asian Fisheries Sciences 13: 12-30.

[17] Bender, J. M., Ampofo, K., Korgenski, K., Daly, J., Pavia, A. T., Mason, E. O., and Byington, C. L. 2008. "Pneumococcal Necrotizing Pneumonia in Utah: Does 
Clarias gariepinus (Burchell, 1822) Obtained from Asaba, Nigeria

Serotype Matter?" Clinical Infectious Diseases 46 (9): 1346-52.

[18] Xu, P. C., and Cao, C. H. 1989. "On Hematology of the Blood of Fishes Cultured on the Lake Pen.” Journal of Fisheries of China 13 (4): 347-52.

[19] Coz-Rakovac, R., Strunyak-Perovic, I., Hacmanjek, M., Topic, P. N., Lipej, Z., and Sastaric, B. 2005. "Blood Chemistry and Histological Properties of Wild and Cultured Sea Bass (Dicentrarchus labrax) on North Adriatic Sea." Journal of Veterinary Research Communication 29 (8): 677-87.

[20] Yousafzai, A. M., and Shakoori, A. R. 2011. "Hepatic Responses of a Freshwater Fish against Aquatic Pollution.” Pakistan J. Zool. 43 (2): 209-21.

[21] Barton, B. A., and Iwama, G. K. 1991. "Physiological Changes in Fish from Stress in Aquaculture with Emphasis on the Response and Effects of Corticosteroids." Annual Review of Fish Disease 1: 3-26.

[22] Adeyemo, O. K., Agbede, S. A., Olaniyan, A. O., and Shoaga, O. A. 2003. "The Haematological Response of $C$. gariepinus to Changes in Acclimation Temperature." Journal of African Biochemical Research 6 (2): 105-8.

[23] Svoboda, M., Kovril, J., Hamackova, J., Kalab, P., Savina, L., Svobodova, Z., and Vykusova, B. 2001. "Biochemical
Profile of Blood Plasma Tench (Tinca tinca L.) during Pre- and Post-spawning Period." Acta Vet. Brno 70: 259-68.

[24] Jan, U., Shah, G. M., and Bhat, A. A. 2012. "Haemato-Biochemical Parameters of Common Carp." Report and Opinion 4 (7): 1-3.

[25] Egborge, A. B. M., Okoro, J. I., Alawani, O. A., and Uraih, N. 1986. "Thermal and Chemical Pollution of Benin River and Its Tributary-Jamison River, Nigeria." Nig. J. Applied Sci. 4: 121-40.

[26] Odum, O. 1992. "The Fish Communities of Ethiope River, Nigeria." Ph.D. thesis, University of Benin.

[27] Sangun, L., Akamca, E., and Akar, M. 2007. "Weight-Length Relationship for 39 Fish Species from the Northeastern Mediterranean Coast of Turkey." Turkish Journal of Fisheries and Aquatic Sciences 7: 37-40.

[28] Bagenal, T. 1978. Method for Assessment of Fish Production in Fresh Water. Oxford, London: Blackwell Scientific Publications, 365.

[29] Kumolu-Johnson, C. A., and Ndimele, P. E. 2011. "Length-Weight Relationships of Nine Fish Species from Ologe Lagoon, Lagos, Nigeria." African Journal of Biotechnology 10 (2): 241-3. 